\title{
Practices and Impeding Factors in the Teaching of English to Young Learners in the First Cycle Public Primary Schools at Nekemte Town, Western Ethiopia
}

\author{
Eba Mijena
}

Institute of Language Studies and Journalism, Wollega University, Post Box No: 395, Nekemte, Ethiopia

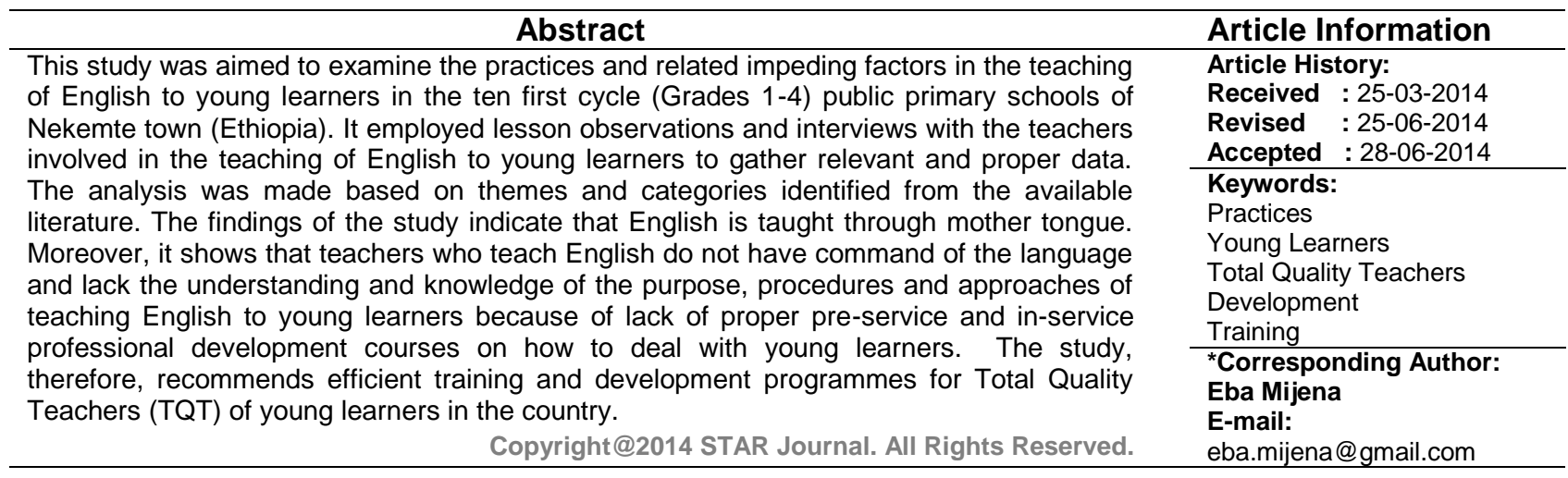

\section{INTRODUCTION}

English is the most dominantly used language in the world. It enjoys world-wide currency because of its political and historical influences. It is taught and used across the world, penetrating the boundaries of race, colors, continents and creed. Currently, it is considered as language of the world than that of a particular community. The amazing thing is that there is no country in the world, including Ethiopia, which is not affected by English language. Teaching English language, along with the native language, from an early age beginning at Grade 1 in primary schools has become a priority with the introduction of the new Education and Training Policy (ETP) of 1994 in Ethiopia with the aim of helping learners learn to communicate.

These recent developments in English language teaching in Ethiopia, like in other countries, take into account the theory of Communicative Language Learning, which seems to be the most powerful learning theory in the history of ELT. The primary argument here is that language is considered as a tool which learners use to make meaning for effective communication and social interaction. The CLT theory claims that the primary goal of language teaching is to enable learners to communicate, using the target language in different contexts with active involvement in the learning process inside and outside the classroom (Richards and Rodgers, 2001; Nunan and Lamb, 2001). The fundamental goal of CLT is to develop learners' communicative competence in target language through communication and interaction with others (Canale and Swain, 1980; Canale, 1983; Swain, 1985).
The new curriculum for English language teaching in Ethiopia adopts this thinking and is designed to meet the needs of primary school young learners. Communication is at the heart of the new curriculum. The major question, however, is "Is English language teaching to young learners at the first cycle primary schools in Ethiopia achieving its purpose? Why do parents complain about the poor performance of their children in the language proficiency when they complete a particular level of education?

Willis (2001) and Cameron (2001) indicate that 'young learners' are children between 7 and 12 years old while children below 7 years of age are considered as 'very young learners'. 'Young children' in this context refers to school children between ages 7-11.It is used interchangeably with 'young learners' and encompasses all children in their Grades 1-4 in the context of Ethiopia who are expected to begin their Grade 1 at the age of 7 and complete First Cycle (Grade 4) at the age of 11. This stage of development is a milestone for the latter development. Children in general want to talk more and share what they have seen and heard. They love doing all things they can and even try to do things they cannot. They experiment with anything that is why it is universally agreed that young children learn actively; they like working with others. That means they are ready to learn and share their thoughts, feelings and ideas with othersthey love listening, speaking, reading, writing and doing things as they occur or appear. Therefore, highly competent and skilled primary school teachers make use 


\section{Eba Mijena}

of this potential and build on it in the teaching of English to young children. These children who want to talk, share thoughts and feelings can learn best and become best learners if best practitioners guide them in the proper way, otherwise they will remain mentally handicapped. This implies that children need special support to learn English.

Though there are no empirical evidences, as Nunan (1999) cited in Shin (2006) indicates, it is widely believed that beginning the teaching of English before the critical period (12 or 13 years of age) will result in the building of more proficient speakers of English. Moreover, Ashton (2002b) cited in Jones and McLachelan (2009) also indicates that:

The ability to understand and communicate in other languages is increasingly important in our society and in the global economy. Languages contribute to the cultural and linguistic richness of our society, to personal fulfillment, mutual understanding, commercial success and international trade and global citizenship. Our vision is clear - we must provide an opportunity for early language learning to harness children's learning potential and enthusiasm; we must provide high quality teaching and learning opportunities in the world of travel and work; we must provide opportunities for lifelong language learning; we must recognize language skills as central to breaking down barriers both within this country and between our nation and others. This is why we must transform our country's capability in languages.

The author stresses that transforming language capability of the nation through teaching other languages will have multifaceted contributions in the global economy, cultural and linguistic richness, personal fulfillment, mutual understanding, commercial success, international trade and global citizenship. Nevertheless, this is determined by the effectiveness of teaching practices and teaching forces. In line with this, Palmer (2008) states that "Everything about the way we teach English profoundly affects children's development and learning". Thus, teachers of young learners have to be competent and capable enough to help children with possible ways of learning the language in the best way. They have to teach them to a world-class standard if the content of their work is to reach the audience it deserves. Success in language learning is impossible and unthinkable without the vital role played by teachers in the classroom. As Palmer (2008) states,

... the good English classroom will always be a fertile ground for new ideas, have an energy about it, be a place where interesting things happen and where there is a creative and reflective approach. This is not to underestimate the sheer hard work involved for teachers and children during periods of change. We can have any number of lists of what ought to be achieved but it is the individual teacher in the classroom who motivates, interests and, above all, values and respects their pupils. Some aspects of teaching and learning may be transformed by technology but we will always need the skill and commitment of teachers who are (xv) good models, of confident and articulate speakers, sympathetic listeners and enthusiastic readers and writers.

\section{Moreover, Horner and Ryf (2007) indicate that}

Creative teachers do not just share the learning objective with the children but may involve them in formulating it. The creative teacher recognises that incidental but
Sci. Technol. Arts Res. J., April-June 2014, 3(2): 201-212

equally important learning may have taken place outside the confines of the learning objective and will involve the children in self- and peer-assessment.

Teachers must have and need to be equipped with the required knowledge. Jones and McLachlan (2009) defined teacher knowledge in the context of primary languages as a) knowledge of the subject (i.e. content of foreign language, foreign language communication skills, and target culture), b) subject-specific teaching methods, c) age-specific teaching methods, d) resources, e) primary curriculum, f) children as individuals, and g) children's learning needs. The categories of teacher knowledge indicated here have similarities with the categories of teacher knowledge by Shulman (1986 and 1987) which includes: content knowledge, general pedagogical knowledge, curriculum knowledge, pedagogical/content knowledge, knowledge of learners and their characteristics, knowledge of educational contexts, knowledge of educational ends, purposes and values, and philosophical and historical background. Similarly, the Ethiopian Ministry of Education (MoE, 2013) has identified a list of teacher knowledge in the context of primary language education which primary English language teachers are required to possess as follows:

a. Knowledge of the purpose: knowing purposes for the English language teaching/learning as a foreign language in Ethiopian context;

b. Knowledge of the language: being able to do with the English language in and outside classrooms;

c. Pedagogical content knowledge: knowing how to help learners develop the English language skills and knowledge that they need in their studies and future careers;

d. Knowledge of language activities or tasks: knowing types of different tasks used for practicing different language skills; being able to modify or adapt illdesigned language activities/tasks in the English textbooks they teach;

e. Knowledge of the subject matter: knowing basic concepts of teaching/learning a foreign/second language theories and practices;

f. Knowledge of assessment: knowing practices of the English language testing and continuous assessments;

g. Curriculum knowledge: knowing the English language curriculum and syllabuses they teach;

h. Knowledge of the learners: knowing about the English language learners in Ethiopian context, and

i. Knowledge of professional development: knowing and practising continuous professional development.

The categories of teacher knowledge identified by the MoE (2013) are in one or another way the same with the categories made by Shulman (1986 and 1987). Teacher knowledge is fundamental to and very important factor in effective teaching, be it at the primary level for young learners or advanced levels for adults. The important issue one has to know of course is that teacher knowledge has to be contextually defined. This means the knowledge required for primary school teacher who always deals with handling language teaching with young learners differs from the one who deals with handling adults. The teaching of English to young learners has its own techniques; it has its own unique features which 


\section{Eba Mijena}

teachers of young learners need to know to be effective in their teaching. Different researchers and writers of teaching English to young learners (e.g. Scott and Ytreberg, 1990; Halliwell, 1992; Phillips, 1993; House, 1997; Rixon, 2000; Moon, 2000; Cameron, 2001; Slattery and Willis, 2001 and Pinter, 2006; MoNE, 2006; McCloskey, Orr and Dolitsky, 2006; Jones and McLachlan, 2009 and Süleyman Nihat, 2010) have recommended that focus should be given to meaning or language use (which has to be illustrated by use of objects, pictures, actions or gesture) than form and the activities should be fun and enjoyable. Moreover, they indicated that the activities should involve performing tasks and create a need to communicate, creating an environment where these young learners feel relaxed. Besides these, the following principles were recommended for the teaching of English to young learners:

a. the use of rhymes, songs, stories, poems, drama, project/theme based approaches and TPR activities.

b. the use of 'chunks' of language should be promoted.

c. the use of L2 as much as possible to conduct lessons.

d. the use of variety of activities.

e. the establishment of classroom routines.

f. the relevance of activities to children's life experience and sense of imagination.

g. the use of activities which are simple enough for children to understand what they are expected to do.

h. the use of demanding but achievable activities.

Teaching English to young learners has its own technique which teachers of young learners need to know to be effective in their teaching. For example, Shin (2006) recommended various techniques for the teaching of English to young learners which include: using visuals, realia, and movement to supplementing activities, engaging learners in making visuals and realia- for example, students can be asked to prepare visuals related to characters used in stories, proper pace and movement from activity to activity- a classroom teacher should not take much time dealing only with one activity for more than 10-15 minutes for young learners. It is therefore recommended to keep proper balance between various activities like quiet/noisy exercises, different skills (listening/speaking/reading/writing), individual/pair work/ group work/whole class activities/ teacher-learner/learnerlearner activities. This will help learners to be more attentive and effective (see Jones and McLachelan, 2009 also). Moreover, Shin emphasizes that organizing lessons in themes/topics, using stories and contexts familiar to students, establishing classroom routines (to properly manage and make the learning of young children effective, it is recommended to establish structured environment, for example, always telling story or poem or playing short game which has to be repeated time and again and engaging them before beginning the lesson to capture their attention and motivate them to learn), using L1 when necessary (e.g. to explain difficult expressions or ideas and give instructions otherwise the maximum use of target language is recommended as it is required to expose children to language learning. Class time should be devoted to target language objectives rather than the teaching of unfamiliar words and expressions however) and collaborating with English speaking community around (e.g. university instructors or students), other
Sci. Technol. Arts Res. J., April-June 2014, 3(2): 201-212

teachers in the school and professionals in the area of teaching English to young learners.

Teachers of young learners in Ethiopia work in the environment where the young learners learn both the L1 (as a subject and as medium of instruction for all subjects except English language) and the English language starting from Grade 1. In the case of Nekemte town first cycle primary schools, children have only the English language classroom to learn and practice English language. Classrooms are the only places to learn English as English is not used anywhere else. Hence, a lot is required from English teachers to model the language, effectively support the children learn it and use the time allotted for course effectively. They need to be sensitive to the difficulties of young children. This implies that primary school English language teachers need to be sensitive to the difficulties young children may experience during a parallel process of learning both a foreign language and mother tongue.

Elsewhere towards the beginning of this paper, it is indicated that there are lots of complaints on the language competence of public first cycle primary young children in Ethiopia. One can, hence, ask "What could be the major source of the problem?" Scholars in the field of language education argue that the teaching of young learners has its own distinct features in the content and methods used. Many agree that the emphasis of language teaching for young learners should be primarily on meaning and communication. As indicated by Cameron (2001) "a centeral principle for teaching young learners is that children should be supported in constructing meaning for every activity and language use in the FL classroom, and that understanding is essential for effective understanding". The existing literature indicates that effectiveness in teaching young learners centers around the teaching practices used with young learners, which has to be understood properly by the practitioners in the area. Hence, teachers of young learners also need to have the required knowledge in these aspects. Moreover, as indicated by Garton, Copland and Burns (2011) citing Graddol (2006)

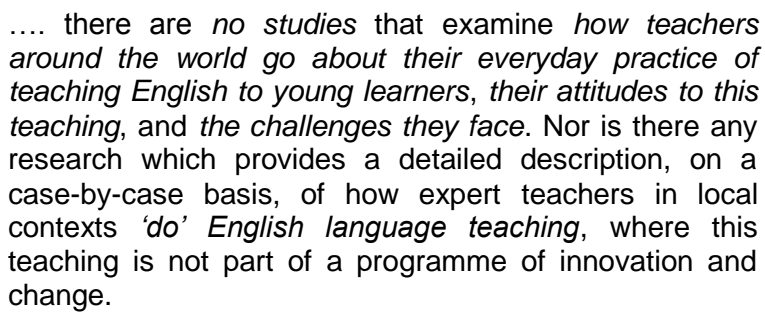

It is very evident that there are gaps in the existing literature in the field of language education, specifically in teaching English to young learners. Therefore, the study herein is designed to fill-in the gaps indicated above.

As indicated earlier, several changes have been made in curricula with change in government in Ethiopia since 1994. The curricula have been made learner-centered and the problem-based approach to teaching-learning has been adopted, which was aimed to lead to effective language learning. Moreover, textbooks were radically changed from the traditional rule-based to the communicative approach, focuses given to activities, Yet, there are complaints by government, parents, teachers and students about the quality of English language 


\section{Eba Mijena}

teaching at all levels while most of them argue that the very root of the problem is laid in the teaching practices. For the poor performance of Ethiopian students in English language skills, university teachers complain the secondary school teachers; the secondary school teachers in turn complain the primary school teachers. The issue of pushing the problem down ladder of the educational levels than owning and sharing has its own problem and can be the point of discussion elsewhere. Yet, it can be argued that primary school teaching in general determines the effectiveness of children in their future education and development. It can serve for laying the foundation because anything which is laid on strong and sound foundation shall lead to success in all aspects. In the same token, the effectiveness in the primary English language teaching determines children's English language ability.

As the focus of the study herein is first cycle primary school English language teaching, the above concerns will make one to ask and investigate the following basic questions:

1. How is English taught to young learners at First Cycle public primary schools in Nekemte?

2. What are the factors, if any, which affect the English language teaching practices in these schools?"

Hence, the major objective of this study is to look at the practices in the teaching of English language at the first cycle public primary schools of Nekemte town and to identify the major challenges, which might affect the effectiveness of teaching English to young learners.

\section{MATERIALS AND METHODS}

This study was intended to find out the current practices and impeding factors in the teaching of English language to young learners in the first cycle public primary schools of Nekemte town. For this purpose, therefore, a descriptive research method was chosen as it is used to specify or describe a phenomenon (Selinger and Shohamy, 1989).

\section{Respondents}

There were 10 public first cycle primary schools in Nekemte town when the study was undertaken. Therefore, the subjects of the study were 15 teachers (hereafter named $\mathbf{T}_{1}, \mathbf{T}_{2}, \mathbf{T}_{3}, \mathbf{T}_{\mathbf{4}} \ldots \mathbf{T}_{15}$ ) who were teaching English language in the first cycle schools in the town. 10 of the 15 teachers were willing to be observed and videorecorded while the remaining 5 were willing to be observed but not to be video-recorded. In the second case, only observation notes were taken. Hence, both categories were included in the study. Among these, only 10 randomly selected teachers were interviewed.

\section{Instruments}

The study employed observations and interviews for data collection. 15 teachers, who showed willingness, were observed. Among these, 10 teachers were randomly selected for interviews. Observations were made for two different purposes: to familiarize children with the observer and the new instrument to be used for recording, and to actually record the lessons to look at the actual practices in the environment of EFL classrooms to young children. This is because it is believed that "there is no substitute for direct observation as a way of finding out about language classrooms" (Nunan, 1989). Interviews were used to collect data on background information of
Sci. Technol. Arts Res. J., April-June 2014, 3(2): 201-212

the respondents and the factors affecting teachers' classroom practices.

\section{Data Analysis}

The data obtained from observations and interviews were video-recorded and tape-recorded respectively. They were analyzed both quantitatively and qualitatively. The qualitative analysis was made based on the categories which emerged from the literature, interview schedules, and observations.

\section{RESULTS AND DISCUSSION \\ Schools}

There were 10 public first cycle primary schools in Nekemte town when this study was undertaken. Hence, all these 10 schools were included in the study so as to get the clear picture of the practices in teaching English language to young learners at the first cycle primary school level in the town.

\section{Gender}

One of the questions in the 'general background information' was to seek information on respondents' gender, which is presented in Figure 1 below.

As it can be seen in the figure, there were 15 (6 male and 9 female) teachers observed and interviewed for the study. This implies that the teachers teaching English language in the public primary schools selected had more female than male teachers.

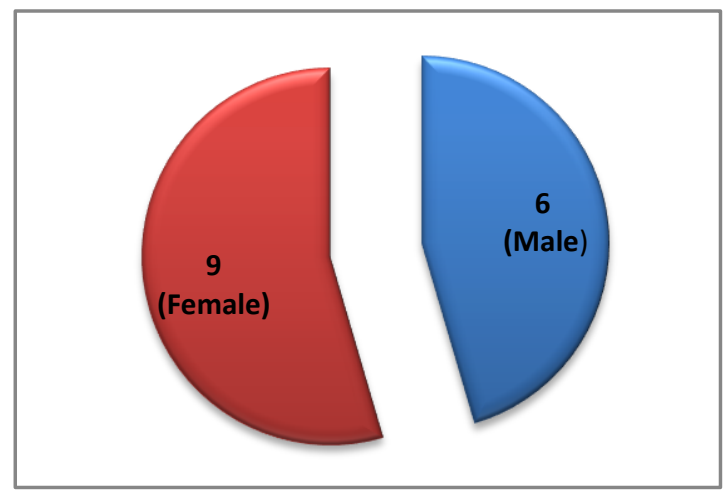

Figure 1: Respondents by gender

Age

Figure 2 shows that the age of first cycle primary school teachers included in the study vary from 25 to 60 years. Hence, one can observe that the majority of them are above 46. This can imply that most the teachers in Nekemte public first cycle primary school teachers are aged.

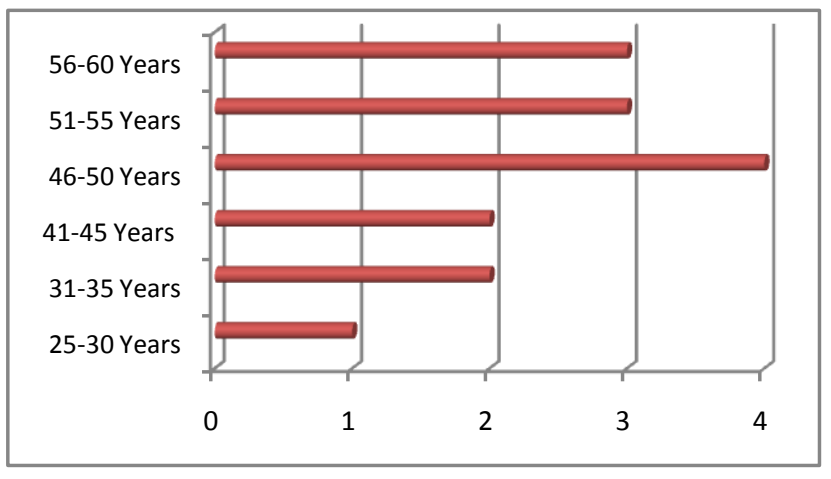

Figure 2: Teachers by age 
Eba Mijena

\section{Qualification}

Figure 3 shows the qualification of teachers who were chosen for the study. As it is depicted in the picture, the majority of teachers teaching English language in Nekemte public first cycle primary schools were Diploma holders during the time of data collection. According to the requirement on the qualification of teachers at this cycle, all had to be with diploma. The major challenge still observed was that there were teachers with Certificates (those who did not have Diploma) but teaching English, which might have adverse effect on the teaching of English at the first cycle primary schools as these teachers did not have training on English language teaching methodology.

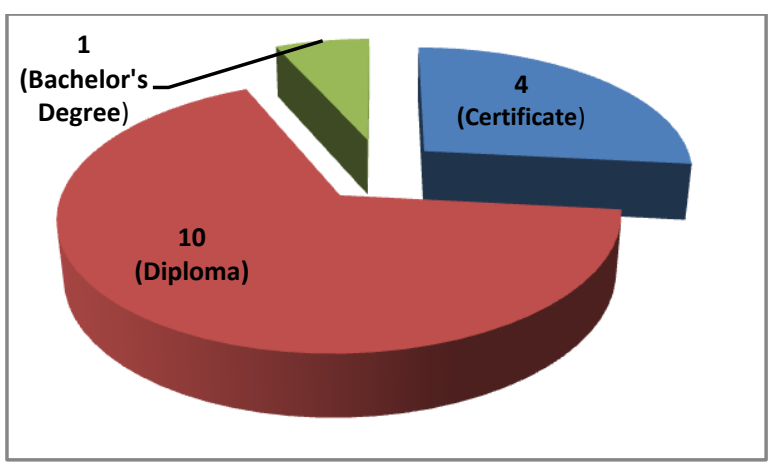

Figure 3: Teachers by qualification

\section{Specialization}

Figure 4 shows that teachers with different specializations (English, Afan Oromo, Social Science, Natural Science, and Language Stream) and with no specialization (those who did not even have Diploma) teach English in the first cycle public schools of Nekemte town. It can be seen that there were only 3 teachers who had Diploma in English while the remaining either specialize in other field of study other than English or not specialized at all. From this fact, it might not be very difficult to imagine the challenges which might face the teaching of English at this level.

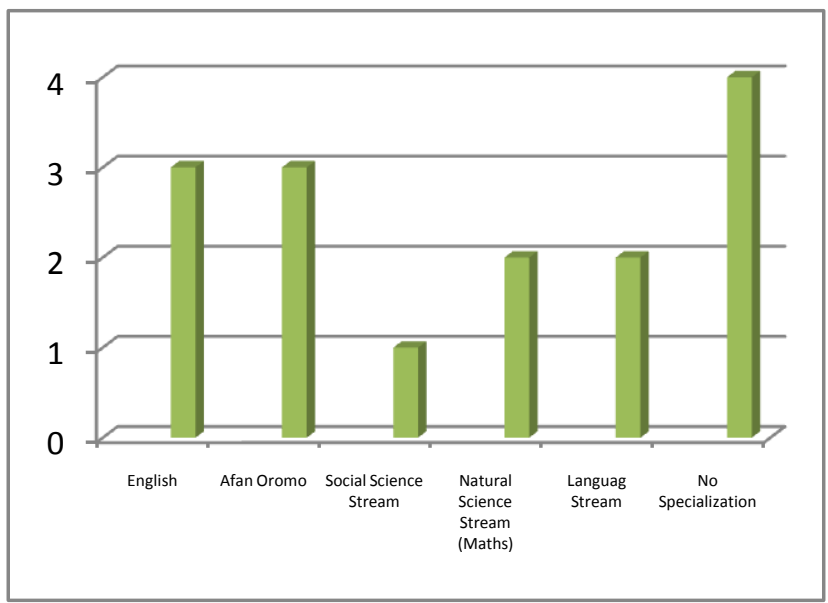

Figure 4: Teachers by specialization

\section{Work Experiences}

Figure 5 below shows the teaching experiences the respondents had at the moment of data collection. Figure 5 indicates that the majority of teachers teaching English language at the moment of data collection had the experience of 26 years and above, but not specifically in the teaching of English language. The experiences were
Sci. Technol. Arts Res. J., April-June 2014, 3(2): 201-212

in teaching other courses than English like Mathematics, Afan Oromo, Science, and the like. Hence, there were no experienced English language teachers at the moment of data collection as they were generalists.

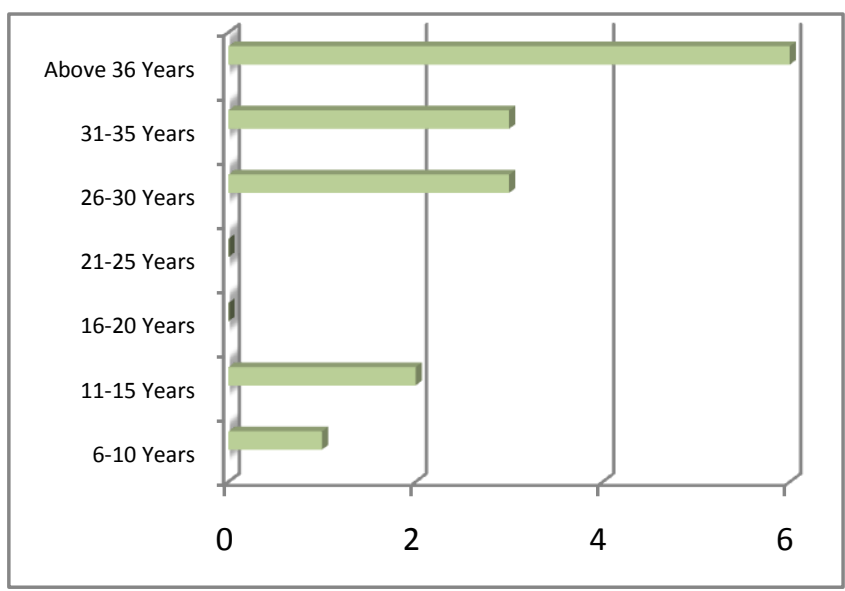

Figure 5: Respondents by their experiences

\section{Choice of ELT Profession and Its Teaching}

Teachers involved in the study were asked (those who had diploma in English) if English language teaching profession was their choice and interest. Surprisingly, all of the teachers said they had the interest of studying other subjects like Afan Oromo, not English. They emphasized that they were forced to study it. Regarding the interest they had towards teaching English in schools, only one teacher (with Certificate) indicated that he loves teaching English. The remaining teachers indicated that they prefer teaching other subjects like Afan Oromo or Civics to teaching English.

From the background information analyzed above, one can see that the majority of teachers teaching English at the first cycle government primary schools of Nekemte town are females. Age-wise, the majority were aged when this data was collected. In the teaching of English (especially as a foreign language), qualification also matters. According to the qualification requirement for the teaching of English at the first cycle primary schools in Ethiopia, the minimum standard set was Diploma. The current situation however indicates that though the majority of the teachers were diploma holders, there were still teachers with Certificate level qualification in Nekemte town schools, which might have some implication on the quality and the practices of teaching English as foreign language. Teachers with the qualification of Certificates even never have courses on the teaching of English, be it methodology or content wise. Therefore it can be possible to observe that there were still unqualified teachers teaching English in the schools.

Another very important factor analyzed here was the issue of qualification where the majority of the teachers teaching English in the primary schools studied did not have specialization in English language teaching. It is not very difficult to assume what difficulties untrained teachers face where even the EFL trained teachers face a big challenge in the teaching of English. As depicted above, some teachers specialized in Afan Oromo (the local language), some even in Mathematics, some in Social Science and some were from TTI and did not have any specialization. Surprisingly, these teachers were teaching all courses given to a particular grade level (for example, 
Grade 1). Regarding the experience of the teachers, almost all were with a minimum experience of 11 years of teaching experience.

\section{Language of Instruction}

One of the objectives of the study was to check the most frequently used language of instruction in teaching English to young learners in the first cycle public primary schools of Nekemte town.

\section{Sample Lessons}

$i \ldots i \ldots i \ldots$ (local language)- checking for what the student has said. The time is $i \ldots i \ldots . .$. English times. Good. Another students! Another students! We did we learn about yesterday ... ih...take English book and exercises book page 55. Page 55...lesson 17 ... lesson 17. Iyi copy the chart your exercise book and as your teacher reads you and last time table last time table out loud iyi. Subject and time iyi environmental science is iyi...environmental science... iyi.. how manyo'clock? Environmental science looking at the teacher's guide... iyi .. What time is mother tongues? lyi...lyi .... 3 O'clock iyi ... 3 O'clock 45 minutes. Very good. Very good. Very good. Looking at the teacher's guide ...Break time....iyi break times (looking at the teacher's guide)...break time...break time is...break time is... how many O'clock break time is? (long silence on part of students)... iyi... 4 O'clock ... 4 O'clock.. how many minutes? ... 4 O'clock 45 minutes. $\left(\mathbf{T}_{1}\right)$ The students were copying note from the blackboard for long time. One of the students talked to a classmate in very low sound. The teacher said "Sayile, hin hojjettu!" (in Afan Oromo, the student mother tongue which means 'do the class work' to the student named Sahile). Going round and telling the students in Afan Oromo what they have to as most of the students were not clear with what they were opted to do. Isaan kun wayyaa attamii uffatu? Bifti uffata isaanii mali? (More than $98 \%$ of the class teaching was conducted in local language) $\left(\mathbf{T}_{2}\right)$.

The whole discussion with the group of students was in local language. No English language was used throughout the whole period. The bell rang before the teacher did nothing. No clear objective, no purpose, and no focused practice. She spent a lot of time copying exercises from the textbook into the chalkboard. I could call this "The Copying Exercises Only!" lesson. Amazingly, the 40 minutes were wasted without any tangible teaching and learning. It was observed that a teacher who is not able to use a single English word in the classroom is teaching children English language. Hence, one can imagine what the consequence will be.

Barnoota keenya darbe keessatti wa'ee 'comparative' ilaalleerra. Maalisheen 'comparative'n? Yes, Chimdessa. Walmadaalchisuu ykn wal bira qabuu. For example, Aboma can you tell me about comparative degree? light...lighter. Thank you very much. 'Comparative'dha egaa kun...baranneerra moo hinbaranne? Gaariidha baayyee. This is the rememberance of our last lesson. Kun yaadachiisa barnoota keenyaa darbeeti...rememberance of our last lesson.Gaariidha dugaa hamma kana yaadachuun keessaniyyuu..baayyee ciccimoodha aboo...gaariidha dhugaa. ( $\mathbf{T}_{3}$, More than $60 \%$ of the class was conductued in local language). Sack is quantity. A sack yeroo jennu maal jechuudha? 'a' and 'an' hinbarannee warroota kana? 'a'n tokko bakka buuti. Qubee dubbifamaa duukaa fayyadamna. Yeroo wanta lakka'amu countable noun waliin deemti. Countable noun jechuun wantoota lakka'amani. Mee ibsamee wantoota lakka'amuu dandaman. For example, we can say pen, book, pencil, goat. 'An' is followed by what? What vowel letters are there? 'Vowel letter' jechuun maal jechuudha? Qubee jechaa mitii? Qubee dubbachiiftuu $\left(\mathbf{T}_{\mathbf{4}}\right)$.

As it can be seen from the sample lessons, teachers in the schools selected for the study dominantly use $L_{1}$ in teaching English to young children. Other teachers $\left(\mathbf{T}_{\mathbf{7}}, \mathbf{T}_{\mathbf{8}}\right.$, $T_{9}, T_{10}$ and $T_{12}$ ) who only copied all the activities from children's textbook which in turn children should copy into their notebooks, taught the 40 minutes in the local language. The wise use of translation is advisable in a few language classroom contexts but as one could see from the script, the use of local language appears on average immediately after one English word or phrase or it occurs throughout. Different scholars suggest that L2 has to be used to conduct lesson as much as possible (Cameron, 2001; Slattery and Willis, 2001 and Pinter, 2006) except during clarifying some difficult concepts or instructions (Shin, 2006). Shin continues to say that "Teachers these days are mostly encouraged to teach English through English, especially at the younger ages" (P.6). Nevertheless, in the case of most first cycle English language classrooms of Nekemte, local language is used for the teaching of the whole lesson.

\section{Approaches Used in Teaching}

This section of the analysis deals with examining the approaches used with teaching young learners in the English language classrooms (see the lesson transcripts).

Take out your book page 55 lesson 17. Teacher opening the teacher's guide. ...lesson 17 ... lesson 17 . lyi copy the chart your exercise book and as your teacher reads you and last time table last time table out loud iyi. Subject and time iyi environmental science is iyi...environmental science... iyi.. how many o'clock? Environmental science looking at the teacher's guide... $\left(\mathbf{T}_{1}\right)$. Take out your exercise book and book $\left(\mathbf{T}_{2}\right)$. What is our subject? Maal baranna?/What do we have now? ( $\left.\mathbf{T}_{6}\right)$ Okay students our topic is talking and writing $\left(\mathbf{T}_{15}\right)$. Kitaaba keessan fuula 145 baafadhaa! Remembers yesterday assignment. What is butchers? Mana fooniiti mitii? Started copying the activities from the student textbook to the chalk board $\left(\mathbf{T}_{\mathbf{7}}\right)$. Open your book page 40 unit 2. Then, started reading the list of food items from the student text. Wrote them on the board. And asked the students to copy into their note books $\left(\mathbf{T}_{\mathbf{4}}\right)$. Take out your book page 129 unit 11- a frog can jump. Fuula dhibbaafii digdamii sagal! (page number repeated in local language) $\left(\mathbf{T}_{8}\right)$. Namni lama as ba'aa gara fuulduraatti (asked for two students to come to the front) andasked them to read the dialogue given in the student textbook $\left(\mathbf{T}_{9}\right)$.

Teachers teaching English to young learners in the first cycle primary schools of Nekemte use different approaches with children in their classrooms during beginning their lessons. From the above sample lesson transcript, one can see that teachers use the following steps and approaches most dominantly in their day-to-day teaching of children, which include:

a. Children are required to open their textbooks (the most dominant first step)

b. The teacher writes/copies all the activities given in the student textbook to the chalk board.

c. The teacher either reads the activities to the children or ask them to read the same. 


\section{Eba Mijena}

d. The children copy the activities from the chalk board to their notebooks.

e. The teacher gives explanation on the activities, mostly in child's L1.

f. A poem or song is taught in reading (dialogue) form than as it has to be.

The above sample lessons show that teachers are book dependent in their teaching and use the following procedures:

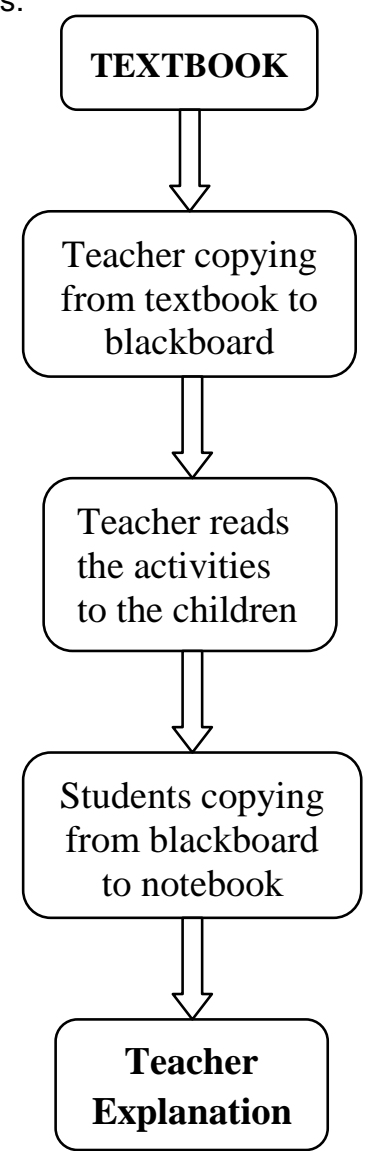

Figure 6: Procedures used by teachers

The following is a song designed for the teaching of greetings:

$\mathbf{T}_{1}$ : Take English book page 59 Good morning. Looking at the book ... lesson 8 (wrote on the board 'Lesson EIGHT'- capital and small letters mixed). Looking at the teacher's guide... sing the lesson eight... the... sing the good morning song with your teacher (reading from the book)... song song sing songs... with your teachers sing songs good morning.

$\mathbf{T}_{1}$ : Say good morning ... good morning... good morning

Ss: Good morning ... good morning... good morning.

$\mathbf{T}_{1}$ : Say good morning ... good morning... good morning

Ss: Good morning ... good morning... good morning.

$\mathbf{T}_{1}$ : How are you?

Ss: How are you?

$\mathbf{T}_{1}$ : How are you?

Ss: How are you?

$\mathbf{T}_{1}$ : I fine ... I fine ... I fine thank you.

Ss: I fine ... I fine ... I fine thank you.

$\mathrm{T}_{1}$ : I fine ... I fine ... I fine thank you.

Ss: I fine ... I fine ... I fine thank you.

$\mathbf{T}_{1}$ : Good after noon ...Good after noon ... good after noon.
Sci. Technol. Arts Res. J., April-June 2014, 3(2): 201-212

Ss: Good after noon ... Good after noon ... good after noon

As pointed out before, the above script was a song where the students were expected to sing. But the way it was presented to the class was not like a song had to appear rather as a dialogue between the teacher and the students. It was rather translated to a prose-like reading approach. Even the teacher was inviting her students to sing the song like this "Who can read? (asking the class) .... Who can read?" The students took turns to stand up and read the song to the class. In spite of the fact that the first cycle primary English textbooks are prepared accommodating songs, poems and dramas, it was observed that the teachers themselves have the problem of dealing with songs in the language classrooms, because of the lack of preparation during the pre-service training programme or lack of sufficient in-service training programmes as they have indicated in the interviews made with them. English is taught based on individualbased and developed style of teaching than the theoretically recommended way of teaching.

The procedures used by teachers in dealing with young learners were with various problems. The first problem was that children were not really giving their attentions and the classrooms were noisy- children busy talking to one another. When the teachers copy the activities from the textbook to the chalkboard (which actually does not add any value to the children's learning than waste of time and energy because the activities are already in the textbooks), the children shout and engage in playing with each other, one beating, pinching, or pushing the other in their seats. This might imply that the strategies or approaches followed do not go with the proper and effective ways of dealing with young children. Different writers and researchers dealing with the teaching of young learners indicate that establishing classroom routines play a vital role in attracting or capturing the attention of young learners (see Shin, 2006, Cameron, 2002). Shin (2006:5) says, "Having basic routines in the classroom can help to manage young learners. For example, to get students' attention before reading a story or to get them to quiet down before an activity, the teacher can clap short rhythms for students to repeat". Thus, the teachers engaged in teaching English to young learners failed to do such very significant principles.

\section{Focus on the Objective}

Take English book page 59 Good morning. Looking at the book ... lesson 8 (wrote on the board 'Lesson EIGHT'- capital and small letters mixed). Looking at the teacher's guide ... sing the lesson eight... the... sing the good morning song with your teacher (reading from the book)... song song sing songs... with your teachers sing songs good morning $\left(\mathbf{T}_{1}\right)$. (The lesson was on how to write a letter). What is our subject? Who is going to tell me? Eenyutu natti hima? What is today by the way? $\left(\mathbf{T}_{6}\right)$ Okay students our topic is talking and writing. Who is going to talk to his partners? Who is going to talk to his partner using his weight and his age. I think you know the meaning of your age, your weight and your height. Now, another we are going to learn about some pronouns I, he, us, them, me, him. Who can use these pronouns in a sentence? (Silence for several minutes). I think you know about pronouns. Pronouns are used instead of nouns. Another we are going to learn about comparison older and younger. These two words are comparison. And shorter and taller and heavier and lighter are comparison. Now we are going to learn the opposite taller and shorter $\left(\mathbf{T}_{15}\right)$. Today, we learn about 


\section{Eba Mijena}

food items egg, sugar, milk, water. Items under packet leenyutu natti hima/who can tell me? We can say a sack of wheat. In activity 2 , the direction says, direction means what? Instruction. Sometimes we say command. .... now we are talking about vowel letters. 'a' how can you pronounce? What about 'e'? Isaan kanaan jechi yoo jalqabe maal fudhata? an egg, an ostrich. What is 'ostrich'? It is the largest bird in the world. Afaanitti yeroo hiiknu maal isheen?/What does it mean in L1? Guchiidha...gosa maali ineen? $\left(\mathbf{T}_{\mathbf{4}}\right)$

The sample lesson transcripts show that there is total astray or deviation from the objectives of English language activities by the teachers. $\mathbf{T}_{\mathbf{1}}$ was to teach about greetings using songs but she was rather reading the songs to the class. The major aim of the lesson was to get the children learn how to greet someone in the morning, afternoon, and in the evening in a song. The assumption was that children themselves engage in singing the song but the teacher was reading it to the children, missing the very objective of the lesson. The difficult thing observed of course was that the teacher herself had a problem of singing a song in language classroom and the children, too. The song was converted to reading aloud by the teacher where the objective was not clear. The case of $\mathbf{T}_{6}$ was a serious issue- nobody could understand the intention of the lesson. In the case of $\mathbf{T}_{15}$, the focuses were a) describing self/introducing self (where children were required to tell about themselves, b) teaching about pronouns, c) teaching about comparison, and d) teaching about opposites. Here, it seems that the teacher has totally lost the purpose. This can be further analyzed.

$\mathbf{T}_{14}$ : Came in, greeted students and began writing "How to ask questions using pronouns" on the board. And wrote two sentences on the board a. What are you doing? b. I am pointing to the Then, he wrote the word "Practice" on the top. Then, he said "Okay...we have learned about pronouns but we don't know how to speak and write we have to stand up and.. come and practice. For example, who is volunteer from the class? I want to tell you something ..... I will tell you starting. I will tell you how to apply." (One of the students came to the front). Ask me the first question (pointing to the question "What are you doing?" he wrote on the board.

S: What are you doing?

$\mathbf{T}_{14}$ : Thought for sometime what to point to... pointed to the roof and said "I am pointing to the roof". In this lesson, the interaction between one student and the teacher continued, the teacher using different words in the place of the word 'roof' such as 'table', 'desk', 'door', 'blackboard', 'girl', 'boy', 'window', and 'wall'. It seems that the attention of the activity was making the children practice learning classroom objects using substitution drills. Students were taking turns to come to the front and demonstrate it for 40 minutes. The teacher did not make the objective clear. He simply wrote the sentences "What are you doing?" and "I am pointing to In his words he told it was an activity to practise using pronouns to ask questions but neither the teacher nor the students were students to practise using pronouns-to identify pronouns, the meaning of pronoun and even they were not given any chance to use different pronouns throughout the 40
Sci. Technol. Arts Res. J., April-June 2014, 3(2): 201-212

minutes so that they can understand the meanings. Hence, in the presentation, one can observe:

a. the lack of clarifying the purpose to students. If children are not clear with the purpose of the lesson and supported to practice in line with it, learning will not happen or take place.

b. the lack of relevance of the practice and the very purpose of the lesson. If it was really practising how to use pronouns, the practice should have not focused on substituting the words black board, duster, table, chair, roof, student, and wall throughout the whole period (40 minutes) repeating over and again. One can therefore ask, "Did students learn about using pronouns?" Absolutely, no. Learning did not take place. The lesson was named "The What Are You Doing " lesson.

In "The What Are You Doing " lesson, it seems that the emphasis was on teaching different objects rather than using pronouns in practice. This is because the children were not made to use pronouns in their practice. This is why I have tried to show that the objective or the very purpose of the lesson was totally forgotten. This might have happen for various reasons like teacher's lack of pedagogical skill. If the objective is missed, the whole thing will be missed. In line with this, Halliwell (1992:2) says "To make the most of the experience for both learners and teachers we need be very clear with what it is we are trying to do. We must try to identify what learning a language in school demands from young children and what it can offer them".

As can be seen from the different sample transcripts, soon the teachers enter the class, they ask the children to take out their textbooks. They either write the activities on the blackboard or read the activities themselves or ask children to read. In all cases, the children, rather than attentively working on the exercises, shout throughout and talk about other issues than working on the activities. Besides the problem of deviating from the objective, all teachers fail to capture the attention of children. In line with this, Shin (2006) indicates that

Young learners function well within a structured environment and enjoy repetition of certain routines and activities. Having basic routines in the classroom can help to manage young learners. For example, to get students' attention before reading a story or to get them to quiet down before an activity, the teacher can clap short rhythms for students to repeat. Once the students are settled down, the teacher can start the lesson by singing a short song that students are familiar with, such as the alphabet song or a chant they particularly enjoy. Here is a chant with TPR that can get students ready to begin the class.

Shin has clearly indicated that establishing classroom routines with young learners will help to manage the class and bring their attention to the lesson. From the lessons observed, this was what most of the teachers teaching English to young children in public primary schools of Nekemte failed to do.

It is therefore possible to observe that a) teachers' deviating from the objective which children should learn, b) lack of focus on the meaning (most teachers give conceptual definitions and mechanically approach the 


\section{Eba Mijena}

lesson. The interviews conducted indicated that teachers lack proper pedagogical training. Classroom teaching need to focus on the objective of the lesson. In classroom teaching, clarifying purpose becomes the most important part of success. If students are not clear with what they are doing in the classroom, it would be the waste of time, energy and resources.

\section{Movement from Activity to Activity}

In the "What Are You Doing "lesson by $\mathbf{T}_{14}$ described above, it was only on the two sentences: "What are doing?" and the "I am pointing to " sentences practised the whole period through substitution drills. There were several similar cases from the lessons observed. For example, $\mathbf{T}_{2}$ entered the class. Vocabulary seems the lesson of the day. No introduction; no revision of previous lesson, started writing notes on the blackboard. The students were busy copying what the teacher has written on the chalkboard into their exercise books. She filled the two sides of the board with note from Student Textbook. What was written on the board reads like the following:

\section{Activity Two}

Write the type, shape and color of clothes the people in the picture are wearing.

Word Bank Clothes: trousers, shirt, scarf Colours: white black, square

1. Kitaw is wearing and

2. Kebede is wearing and

3. Omer is wearing

4. Kalahu is wearing and

She did not give any direction or instruction for the students to work on the class work. Children were in confusion throughout the 40 minutes on how to do and what to do. They were shouting; some of them were beating one another, playing with each other. The children were not engaging in language practice. This was the copying only activity, which did not have variety.

To illustrate more examples, in the lessons 'Good Morning' by $\mathbf{T}_{\mathbf{1}}$ and 'What Are You Doing' by $\mathbf{T}_{\mathbf{1 4}}$ described elsewhere in this paper, the teachers $\mathbf{T}_{\mathbf{1}}$ and $\mathbf{T}_{\mathbf{1 4}}$ did not move from activity to activity. $\mathbf{T}_{\mathbf{1}}$ did not vary her activities the whole period- the demonstration was made by the teacher or the student and the whole class. It was a 'repetition drill' kind of exercise for 40 minutes. The whole class was repeating after the teacher or a student. $\mathbf{T}_{14}$ used the substitution drill throughout the 40 minutes. The two lessons lacked both relevance (deviate from the objective) and variety. Let's look at a lesson taught by $\mathbf{T}_{3}$.

$\mathbf{T}_{3}$ : sked what the previous lesson was "what did we learn yesterday?"

Ss: not audible....... children were shouting....busy taking to one another.

$T_{3}$ : Keep quiet! What about the other? What about the other? Yes, Chimdessa!

S: Most were still busy playing with other colleague. (Chimdessa): Yesterday learning...yesterday learning...

T: Yes, yesterday about what? About .... Not audible. What else? What else? Yes, Aboma!

S: Adverbs
Sci. Technol. Arts Res. J., April-June 2014, 3(2): 201-212

T: Adverbs. Adverbs. What are the adverbs? What are the adverbs? Do you remember? Okay, Dinkissa!

S: Always.

T: Always! Adverbs. Adverbs. Always. What else? The adverbs. Sahara!

S: Never.

T: Never (wrote on the board). What else? What else? Sahara!

S: Often (not audible).

T: What? Often (wrote on the board). What else? What else? Yes, Chimdessa!

S: Sometimes.

The above lesson transcripts indicate that teachers focus on single-approach activity type throughout the 40 minutes. It was a traditional teacher-centered 'QuestionAnswer" type activity. It began as a revision lesson but was taught throughout the whole period. The first sample transcript indicates that the teacher began with asking what children learned the day before about adverbs. Then, he continued asking the types of adverb they learned before like always, never, sometimes, often, rarely, usually, occasionally and so on repeating again and again over the whole period. I called it the "What else" lesson. The aim of the lesson seems seeking to list the adverbs. It was revision of previous lesson throughout the whole period whose objective was not clear- either to connect or to the present lesson or any other objective. Children cannot attentively listen for long time on such activities. Hence, moving from activity to activity seems the best way to keep the momentum in the class. In connection with this, Shin (2006:4) says "... if you are teaching a song or telling a story, don't stay on that song or story the whole class time. Follow up the song or story with a related TPR activity to keep the momentum of the class going. Then have students play a quick game in pairs". This implies that teachers need to vary the activities so as to capture the attention of young learners and motivate them learn the language. Despite all these facts, however, the teachers teaching English to young learners failed to vary their approaches.

\section{Language Command}

Consider the following lesson transcripts

What did we learned yesterday? What did you learned yesterday? And What did you learned yesterday? Long silence! Students could not say anything. Take your exercise book (the teacher opening her teacher's guide). Yesterday we learn about... . We did we learned about yesterday. iyi.. how many o'clock environmental science? (from Grade 3lesson by $\mathrm{T}_{1}$ ). We have studied yesterday about what? $\left(\mathbf{T}_{6}\right)$ Remembers yesterday assignment? Eenyutu natti hima?/Who can tell me the assignment I gave you yesterday? ( $\left.\mathbf{T}_{7}\right)$ A FROG can Jum (to write the title 'A Frog Can Jump'-mixing capital and small letters). A bird can fly-the word 'fly' read as /fli:/. $\left(\mathbf{T}_{8}\right)$ Take turns to miming from the word banks, the word 'miming' pronounced as /miminng/ $\left(\mathbf{T}_{10}\right)$ What to learn about yesterday? Today lesson is lesson four. $\left(\mathbf{T}_{12}\right)$.

One of the teacher knowledge identified by the MoE (2013) in the context of primary English language teachers is the ability to do with the English language in and outside the classrooms. This is an important element required from the teachers as they are the only source of English in the context of first cycle public primary schools 


\section{Eba Mijena}

of Nekemte. Hence, the above problems might imply that the teaching of English at the first cycle primary schools in Nekemte is suffering from the lack of proficient language teachers as can be observed from the lesson script cited above. There were cases where teachers even could not utter a single grammatically or logically correct sentence over the 40 minutes he/she was teaching the lesson.

\section{Existing Challenges}

This section was aimed to exploring factors which affect the teaching of English to young learners in the first cycle primary schools of Nekemte. Ten of the instructors were interview. These interviews were transcribed. The analysis made was based on the categories or thematic topics emerged from the interviews. There were different factors identified from the interviews made with teachers teaching in the first cycle primary schools of Nekemte.

\section{Lack of In-service Training}

Many of the interviews conducted with teachers teaching first cycle primary schools in Nekemte reveal that teachers have never had training on teaching English language to young learners.

\section{Sample 1}

R: Did you have any in-service training in teaching English?

$\mathbf{I}_{1}$ : Yes

R: What was the specific topic of the training?

$\mathbf{I}_{1}$ : CPD and Induction

\section{Sample 2}

R: Did you have any in-service training in teaching English?

$\mathbf{I}_{\mathbf{2}}$ : Yes

$\mathbf{R}$ : What was the specific topic of the training?

$\mathbf{I}_{2}$ : improve English

R: How often did you have such training?

$\mathbf{I}_{\mathbf{2}}$ : Once since my teaching.

\section{Sample 3}

$\mathbf{R}$ : Did you have any in-service training in teaching English?

$\mathbf{I}_{3}$ : Yes

R: What was the specific topic of the training?

$\mathbf{I}_{3}$ : Workshop

R: What was it about?

$\mathbf{I}_{3}$ : About skills.

R: Which skills?

$\mathbf{I}_{3}$ : Vocabulary and reading

The above sample transcripts show that teachers teaching first cycle primary schools in Nekemte town had some trainings on Induction, CPD (Continuous Professional Development) and ELIP (English Language Improvement Programme). These training programmes were generic and prepared for all teachers teaching at all levels, not specifically designed for first cycle primary school English language teachers. These trainings happened very rarely (i.e. not continuously) and all were not relevant to the teaching of English to young learners in all aspects, be it in content taught and the methodology which has to be used with teaching English to young learners. Besides these, teachers lack training on the improvement of language proficiency. These might imply that first cycle primary school English language teachers in Nekemte town lack properly planned relevant and sustainable professional development programmes

\section{Lack of Proper Pre-Service Training}

Teacher preparation plays a significant role in producing well prepared teaching force. Undoubtedly,
Sci. Technol. Arts Res. J., April-June 2014, 3(2): 201-212

therefore the preservice teacher preparation has to serve its purpose. A teacher education programme which prepares teachers for Kindergarten, first cycle primary school, second cycle primary school or any higher level has to be in line with the very objective of teaching at these various levels. Nevertheless, the interviews made with teachers teaching first cycle primary schools in Nekemte reveal that the preservice teacher preparation programmes do not give attention to preparing teachers for the level.

\section{Sample 1}

R: Did you have any course on teaching English to young learners during your college training?

$\mathbf{I}_{4}$ : No

R: Is there any difficulty that you face because you have not taken such course?

$\mathbf{I}_{4}$ : Many problem. One poems, short story, song at school teaching but no how teach it.

R: You mean you face difficulty of teaching poems, songs and short stories?

$\mathbf{I}_{4}$ : Yes, difficult. Akkatti faarfatamutu cima (Afan Ormo which means the way poems should be recited and songs should be sung is difficult)

\section{Sample 2}

R: Did you have any course on teaching English to young learners during your college training?

$\mathrm{I}_{4}$ : No

R: Is there any difficulty that you face because you have not taken such course?

$\mathbf{I}_{4}$ : Yes. Challenges of some activities, many singing sons, many reading poems and others difficult.

$\mathbf{R}$ : What are the challenges related to activities?

$\mathbf{I}_{4}$ : Children don't speak English...not read song, poem and ....shout ...

The above sample transcripts show that teachers teaching English in the first cycle primary schools of Nekemte town did not have courses related to the teaching of English to children. The teacher preparation programmes need to focus and must be in line with the objectives and contents of language education programme at first cycle primary schools. Hence, as indicated earlier, the teaching of English to young learners in all aspects be it in content taught and the methodology which has to be used with teaching English to young learners has to be taken into account in teacher preparation programmes.

\section{Lack of Interest to Teach Young Learners}

It is believed that teaching English to young learners is challenging (Halliwell, 1992). It needs commitment to support children learn to communicate or use the language. But most of the teachers interviewed indicated that they were not happy and comfortable with teaching children (see the sample transcript).

\section{Sample 1}

R: Are you happy for teaching children?

$\mathbf{I}_{\mathbf{4}}$ : Teaching them is difficult....shouting, disturbing, not listening.

$\mathbf{R}$ : Is there any other difficulty?

$\mathbf{I}_{4}$ : They don't know English... talk in local language.

R: What do you do to solve such difficulties?

$\mathbf{I}_{\mathbf{4}}$ : I make them keeping quiet; punish strong distrbers. Also teach in Afan Oromo to understand them the English. 


\section{Sample 2}

R: Are you happy for teaching children?

$\mathbf{I}_{5}$ : Teaching them poems, drama and songs difficult.

$\mathbf{R}$ : Why are they difficult?

$\mathbf{I}_{5}$ : Students do not know.

The above sample transcripts indicate that teachers indicated that they are not happy with teaching young learners for various reasons, which include:

a. Young children shout, and do not listen in the class.

b. They find difficulty to communicate in English.

c. They have challenges to recite poems, to engage in drama activities and to sing in English.

Nevertheless, it is not very difficult to understand that it is not the issue of young learners' language learning difficulty but the issue is related to teachers' a) attitude and commitment to support children learn the language and b) lack of proper knowledge of methodology to teach young learners. It is obvious that children do not have patience to listen for long period of time. When they sit in classrooms, they shout and enjoy talking to their classmates or even talk to themselves but the wellprepared primary school teacher can use various strategies like establishing classroom routines to attract the attention of young learners (see Shin, 2006). Earlier it has been indicated that one of the factors which affect the teaching of English at first cycle primary schools is the lack of proper preservice and in-service training programmes or courses on English language methodology used with young learners.

\section{CONCLUSIONS}

The study indicated that the majority of primary English teachers have the minimum qualification (i.e. diploma in teaching) to teach at first Cycle primary school level in the schools even if professionalizing does not mean professionalism. As Crandall (1993) indicates, professionalizing, which is status improvement, does not guarantee the development of competence. The study has further indicated that English language teaching and learning practices in primary schools are still teachercentered and grammar-based, the medium of instruction is the students' mother tongue, classrooms are organized in whole-class traditional approach, contributing very little to the quality of English language teaching and learning in Ethiopian primary schools. The study indicated that

- Teachers teaching English to young learners at first cycle public primary schools in Nekemte town lack the required qualification and specialization.

- Teachers teaching English at first cycle public primary schools in Nekemte town lack expertise in both subject knowledge and subject-specific pedagogy.

It was also observed that there were gaps in the 1) preparation of English language teachers for the teaching of young children for the first cycle primary level, 2) provision of regular and sustainable relevant in-service training to help teachers deal with primary level contents, methods and child behaviour, 3) teachers' attitude towards supporting children (this is of course not a dominating factor).

Hence, if Ethiopia has to be competent in a dynamic global situation, it has to take proper measures to improve the quality of its primary level teaching force. Currently, recruitment of candidates for primary English language teacher education in Ethiopia is made from those who are not able to pass the Grade 10 matriculation national examination. Besides this, the primary English teachers are generalists and even those who studied English were made to join and teach the course not based on their interests. Another very critical challenge observed was teachers teaching English to young learners in Nekemte town did not have any pre-service or in-service training courses on teaching English to young learners. They did not yet have proper conceptual and pedagogical knowledge and skill to deal with young learners. Therefore, responsible bodies should take steps to prescribe qualifications in accordance with the needs and competencies for teaching English to primary young children. Teaching young children is all about creating the future scientists, philosophers, economists, critical thinkers. It is where one has to lay the proper foundation for what has to happen in the rest life of a child. This reminded me of a biblical story of building a house on rock which will be a guarantee for the better effect of the house but on the contrary building a house on sand which does not have a good foundation. Builders who lay a reliable, strong, comfortable foundation create future scientists. But the most viable problem is that these builders are not themselves built on such foundation. There was also another analogy of a good tree which does not bear a bad fruit and a bad tree which does not bear a good fruit, each tree is recognized by its fruit.

The Foundation Matters! It is very clear that the foundation of everything matters- be it an idea or a material thing. Bad foundation leads to bad end. Weak foundation makes and results in probably weak and even the worst end. I am sure that everybody has heard about the Calgary Tower. This tower is 190.8 meters high. The total weight of the tower is 10,884 tones. The most surprising thing however is that 6,349 tones of the total weight are below the ground. What does this show? Greatest buildings have strong foundation. This analogy will perfectly work in education. The education which is not founded on strong foundation results in producing human capital which is not well equipped with the necessary skills and knowledge. The foundation is the primary teaching and the primary teachers. These have to be laid on perfect foundation. For this, we need quality teachers of young learners. By quality teachers I mean teachers who are well equipped with skills, knowledge and attitude required to teach young children which I call Total Quality Teachers (TQT). Hence, the following issues need to be the very top priority areas for the improvement of the existing practices and challenges:

$\checkmark$ The proper selection of teachers of English to young learners.

$\checkmark$ Designing per-service ELT course related to 'teaching English to young learners' for first cycle primary school English language teachers.

$\checkmark$ In-service programmes which address the 'teaching of English to young learners' become mandatory to immediately change the existing problem. Here, teachers need intensive training on the textbooks they are currently using.

$\checkmark$ The use of teacher-centered traditional approach to teaching English and the use of $L_{1}$ are dominating the first cycle primary school English language teaching classrooms. Hence, an intensive training is required 


\section{Eba Mijena}

both during the preservice and in-service primary teacher preparation on communicative language teaching methodology, content, knowledge of the learners, etc, where they design, evaluate, adopt or adapt tasks as the requirement of the training programme.

$\checkmark$ Teachers need courses on language proficiency and classroom language to alleviate the lack of confidence in using English during the classroom teaching.

\section{REFERENCES}

Broughton, G., C. Brumfit, R. Flavell, P. Hill and A. Pincas. (1980). Teaching English as a Foreign Language (Second Edition). Rotledge: London and New York.

Cameron, L. (2001). Teaching Languages to Young Learners. UK: Cambridge University Press.

Canale, M. (1983). From communicative competence to communicative language pedagogy. In: Alatis J.E. (Ed.), Georgetown University round table on languages and linguistics: Language, Communication, and Social Meaning (pp. 223-237). Washington, D. C.: Georgetown University Press.

Canale, M. and Swain, M. (1980). Theoretical bases of communicative approaches to second-language teaching and testing. Applied Linguistics 1(1): 1-47.

Crandall, J. (1993). Professionalism and Professionalization of Adult ESL Literacy. TESOL Quarterly 27(3): 497-515.

Garton, S., Copland, F. and Burns, A. (2011). Investigating Global Practices in Teaching English to Young Learners. ELT Research Papers 11-01. British Council: London.

Halliwell, S. (1992). Teaching English in the Primary Classroom. New York: Longman Group UK Ltd.

Horner, C. and Ryf, V. (2007). Creative Teaching: English in the Early Years and Primary Classroom. Routledge: London and New York.

Jones, J. and McLachlan, A. (2009). Primary Languages in Practice: A Guide to Teaching and Learning. New York: Open University Press.
Sci. Technol. Arts Res. J., April-June 2014, 3(2): 201-212

McCloskey, M.L., Orr, J. and Dolitsky M. (edts) (2006). Teaching English as a Foreign Language in Primary School: Case studies in TESOL Practice Series. USA: Teachers of English to Speakers of Other Languages. Inc (TESOL).

Ministry of Education (2013). National Standards for the English Language Teachers (Final). Addis Ababa, June 2013.

Moon, J. (2000). Children learning English. Oxford: MacMillan Heinemann.

Palmer, S. (2008). Foreword, in Mallett M. (ed.), The Primary English Encyclopedia: The Heart of the Curriculum ( $3^{\text {rd }}$ edt). London and New York: Routledge Tylor and Francis Group Ltd.

Pinter, A. (2006). Teaching Young Language Learners. Oxford: Oxford University Press.

Richards, J.C and Rodgers, T.S. (2001). Approaches and Methods in Language Teaching, CUP.

Rixon, S. 2000. Optimum age or optimum conditions? Issues related to the teaching of languages to primary age children. http://www.britishcouncil.org/english/eyl/article $01 / \mathrm{html}$

Scott, W., and L. H. Ytreberg. (1990). Teaching English to children. London: Longman.

Shin, K. J. (2006). Ten Helpful Ideas for Teaching English to Young Learners. English Language Teaching Forum 2: 213.

Shulman, L. (1986). Those Who Understand: Knowledge Growth in Teaching. Educational Researcher 15(2):4-14.

Shulman, L. (1987). Knowledge and Teaching: Foundations of the New Reform. Harvard Educational Review 57(1): 122.

Süleyman Nihat Ş.A.D. (2010). Theory-practice dichotomy: Prospective teachers' evaluations about teaching English to young learners. Journal of Language and Linguistic Studies 6(2): 22-53. 